\title{
Chemical Basis for Beef Charqui Meat Texture
}

\author{
Elza Y. Youssef ${ }^{1,2}$, Carlos Eduardo Rocha Garcia ${ }^{3}$, Fábio Yamashita ${ }^{2,3}$ and Massami \\ Shimokomaki ${ }^{1,2,3 *}$ \\ ${ }^{1}$ Graduate Program on Food Science, Faculty of Pharmaceutical Sciences, University of São Paulo, São Paulo, SP, \\ Brazil. ${ }^{2}$ Department of Food and Drugs Technology, ${ }^{3}$ Graduate Program on Food Science Agricultural Sciences \\ Center, Londrina State University, P. O. Box, 6001, CEP 86051-970 Londrina, PR, Brazil
}

\begin{abstract}
This work evaluated the relationship of charqui meat (CHM) chemical composition with the tenderness throughout its production. CHM was prepared from beef Vastus lateralis of 4-5 years old. Shear force of fresh CHM showed an approx. 3-fold increase in toughness compared to the raw material while, in the case of cooked CHM it was 6-fold increased in relation to the raw charqui. The moisture content decreased by 39.0 and $58.0 \%$ ( $p<0.05)$ for uncooked and cooked CHM, respectively, in relation to the raw material. Mathematical modeling of the influence of these meat components showed that shear force increased exponentially with the loss of moisture. The texture of CHM was the result of a multitude of factors involving myofibril proteins which promoted dynamic biochemical events such as the binding of water molecules. It was the amount of the latter which ultimately determine the final charqui meat texture.
\end{abstract}

Key words: Collagen crosslinking, water activity, intermediate moisture meat product, myofibril proteins

\section{INTRODUCTION}

Charqui has been considered as an intermediate moisture meat product (Shimokomaki et al., 1998, Torres et al., 1994). Intermediate moisture meat products (IM) are processed almost in every country and as refrigeration costs increase, IM gains renewed interest (Chang et al. 1996). After drying, the IM product reaches an Aw of 0.6-0.90 at ambient temperature (Ledward, 1981). Charqui meat (CHM) uses hurdle technology (Leistner, 1987); salt, sodium nitrite, dehydration and packaging are hurdles sequentially applied to inhibit pathogenically microorganisms (Torres et al. 1994; Shimokomaki et al. 1998, 2003).

The texture sensation of meat is influenced by the presence of several factors including the amount of intramuscular fat, water holding capacity, the state of the actomyosin complex and the quantity and, mostly, the quality of collagen. Earlier works by Bailey and co-workers demonstrated that collagen covalent cross-linking mediated by lysyl oxidase enzyme increased with the ageing of animals (Bailey and Shimokomaki, 1971; Robins et al. 1973), and correlated with increased toughness. Indeed, hydroxylysinoketonorleucine (HLKNL), the main form of collagen crosslinking in an immature animal decreases with aging (Shimokomaki et al., 1972) and is replaced by hydroxylysylpyridinium (HP) (Fujimoto et al., 1977; Eyre and Oguchi, 1980). HP has been shown to be related to increased toughness (Nakano et al., 1991; Bosselman et al.; 1995; Coro et al., 2002) although this relationship has been questioned (Avery et al., 1996). In this work, we report the measurement of tenderness and its

\footnotetext{
${ }^{*}$ Author for correspondence
} 
relationship to both HP concentration and moisture throughout the processing. A mathematical modeling was used to predict the impact of both components on CHM tenderness.

\section{MATERIALS AND METHODS}

Six samples of Vastus lateralis muscle, in Brazil popular known as patinho, from zebu breed aged 4-5 years old weighing approximately $4.0 \mathrm{~kg}$ each were used. This muscle has been shown to possess a relative high HLKNL concentration (Shimokomaki et al., 1972). The charqui processing steps followed the techniques described elsewhere (Torres et al., 1994; Shimokomaki et al., 1998). Essentially, fresh tissues were immersed in $20 \% \mathrm{NaCl}(\mathrm{w} / \mathrm{v})$ solution for approximately $10 \mathrm{~h}$ followed by dry salting on a concrete floor for five days. Subsequently, the meat pieces were stacked into piles separated from each other by the layers of coarse marine salt (approx. $1 \mathrm{~mm}$ thick). After about $8 \mathrm{~h}$, the meat was restacked and the uppermost meat pieces were repositioned at the bottom of the new piles. The maneuver was repeated every $24 \mathrm{~h}$ for five days and, after washing to remove the excess salt from the meat surface, samples were placed on wooden rails and subjected to drying. This stage was carried out directly in the sun at a temperature of up to $40^{\circ} \mathrm{C}$ for three days. At night, the meat pieces were collected and piled on the concrete floor and covered with a tarpaulin. The salted products were finally vacuum packed. All fresh tissue samples were kindly donated by Fripar Indústria e Comércio de Produtos Alimentícios, Londrina, Paraná State, Brazil where the charqui meat was processed.

Samples of $150-200 \mathrm{~g}$ were vacuum packed and cooked in a water bath until $75-78^{\circ} \mathrm{C}$ internal temperature as measured by a Hanna thermocouple, model HI 8313, (Co. City, State) USA. Samples were cooled to room temperature and the meat surface was dried with absorbent paper (Avery et al., 1996).

Moisture, ash, protein and lipid were determined according to AOAC (1995) methods. Aw measurement was carried out with Aqualab equipment model CX-2, Ann Arbor, MI, USA. Collagen quantification was based on the Woessner technique (1961). Basically, 1.0g of ground intramuscular sample was hydrolyzed with distilled $6 \mathrm{~N} \mathrm{HCl}$ at $105^{\circ} \mathrm{C}$ for $18 \mathrm{~h}$. The hydroxyproline concentration was determined by reacting with p-dimethylaminobenzaldehyde Collagen was determined by multiplying by the factor 8.0 (Kolar, 1990) as previously reported in Coro et al. (2002).

Hydroxylysylpyridinium (HP) was determined as described by Coro et al. (2002). Essentially, freeze-dried samples of 20-50 mg were hydrolyzed with $6.0 \mathrm{M} \mathrm{HCl}$ at $110^{\circ} \mathrm{C}$ for $24 \mathrm{~h}$. To remove the non-crosslinking amino acids, the hydrolyzates were initially separated on a CF1 cellulose column (Sigma X, St. Louis, MO, USA) (Skinner, 1982). HP was analyzed quantitatively on a Shimatzu HPLC model RF-535, (Shimadzu Co., Kyoto, Japan), with a Supelco (C18)X reverse phase column (Eyre et al.,1984; Eyre, 1987). The location of HP was confirmed with an authentic HP standard. Meat texture was measured by Warner-Bratzler shear force using a SMS Texture Analyser, TAXT2i model, linked to a microcomputer based on techniques described by Bouton et al. (1971).

Several mathematical models were tested to correlate the shear force data as a function of moisture content and HP concentration of the meat samples, using the Nonlinear Estimation and Multiple Regression Modules of Statistics for Windows 5.0 (Statsoft, 1995). The Simplex and Quasi-Newton estimation method was used to calculate the model coefficients.

All the measurements were carried out in triplicate and results were evaluated with Statistics for Windows 5.0 (Statsoft, 1995) for analysis of variance, multiple linear regression, Tukey's and Student's t tests.

\section{RESULTS AND DISCUSSION}

Table 1 presents the proximate chemical composition of fresh $V$. lateralis muscle and its derivative CHM from animals 54 months of age. Fig. 1 is a schematic representation of structural changes in charqui meat throughout the processing from fresh tissue to desalted charqui meat and its respective heat treatment Although the value of ash was slightly above the official legislation of $15 \%$ for CHM (Brasil, 1962), this composition is similar to CHM from Sternomandibularis m., Sternomaistoideu $\mathrm{m}$. and Latissimus dorsi $\mathrm{m}$. (Torres et al., 1994; Shimokomaki et al., 1998). 
This result corroborated the assumption that the intermediate final value of 0.75 corresponded to the saturation point value of $\mathrm{NaCl}$ solution. It appeared that the salt strongly inhibited the diffusion to the interior of the meat, thus, stabilizing the interrelationship of $\mathrm{NaCl}$ association with the moisture and meat proteins and, irrespective of the salt amount and drying procedure. The Aw value remained constant because of the chemical equilibrium already reached between $\mathrm{NaCl}$, meat proteins and water (Torres et al., 1994).

Table 1 - Mean ( \pm s.d.) of proximate chemical composition (g/100g of sample), collagen content, Aw values of meat and uncooked charqui meat from beef Vastus lateralis $\mathrm{m}$.

\begin{tabular}{lcc}
\hline Composition & Fresh meat & Charqui meat \\
\hline Moisture & $76.1( \pm 0.6)$ & $46.4( \pm 2.4)$ \\
Protein & $21.4( \pm 0.7)$ & $26.3( \pm 0.5)$ \\
Lipid & $1.1( \pm 0.1)$ & $2.5( \pm 0.5)$ \\
Ash & $1.1( \pm 0.1)$ & $23.3( \pm 0.3)$ \\
Insoluble Collagen & $0.7( \pm 0.1)$ & $1.1( \pm 0.1)$ \\
Aw & $0.99( \pm 0.01)$ & $0.75( \pm 0.01)$ \\
\hline
\end{tabular}

Table 2 showed that $V$. lateralis muscle had an initial content of $0.140 \mathrm{~mol} \mathrm{HP} / \mathrm{mol}$ of collagen. The results confirmed the pattern found in other muscles by different authors (Steinhart et al., 1994; Bosselmann et al., 1995). On the other hand, in CHM from the same muscle, these was 0.084 mol HP/mol of collagen. During the harsh conditions of 8-12 days of processing, samples were submitted to $2-3 \mathrm{M} \mathrm{NaCl}$ and the temperature reached $40-45{ }^{\circ} \mathrm{C}$ (Shimokomaki et al., 1998). It has been shown that, under these conditions, at the ultrastructural level there was shrinkage of 20$30 \%$ of CHM compared to the original fresh meat making it tougher (Biscontini et. al., 1996). Although there was a loss of soluble collagen, the remaining protein residue fraction was located at the enlarged charqui perimysium sheath. In fact, since there was, as expected, an increase in the concentration of insoluble collagen (Table 1), HP should also increase concomitantly. However, contrary to the expectation, there was a noticeable loss of approximately $40 \%$ of HP during charqui processing (Table 1). The effect of cooking temperature was also evaluated. The concentration of HP remained constant in both fresh and cooked meat and a similar pattern was observed for the uncooked and cooked $\mathrm{CHM}$ at $78^{\circ} \mathrm{C}$ for $60 \mathrm{~min}$ (Table 2).

Table 2 also shows the measurement of the meat samples texture using Warner-Bratzler shear force. The toughest sample evaluated was cooked CHM followed by the uncooked, samples which were much more tender. Although the proportion of HP was similar in both the samples, the shear force value was about three times higher in the cooked than in uncooked charqui meat (Table 2). CHM is routinely consumed by desalting using exhaustive washing (decrease of salt content from 15 to $3 \%$ (Pinto et al., 1998) and thereafter cooked. Again, cooked and desalted CHM was tougher than desalted uncooked CHM (Table 2).

Table 2 - Mean ( \pm s.d.) of hydroxylysylpyridinium (HP) contents (mol/mol of collagen), Warner-Braztler shear force $(\mathrm{N})$ and moisture content $(\mathrm{g} / 100 \mathrm{~g}$ sample) evaluated during preparation of charqui from Vastus lateralis $\mathrm{m}$.

\begin{tabular}{lccc}
\hline Samples & HP & Shear force & Moisture \\
\hline Fresh tissue & $0.140^{\mathrm{a}}( \pm 0.040)$ & $17^{\mathrm{d}}( \pm 4)$ & $76.0^{\mathrm{a}}( \pm 0.6)$ \\
Cooked fresh meat & $0.140^{\mathrm{a}}( \pm 0.051)$ & $52^{\mathrm{c}}( \pm 4)$ & $61.5^{\mathrm{b}}( \pm 1.0)$ \\
Charqui meat & $0.084^{\mathrm{a}}( \pm 0.042)$ & $97^{\mathrm{b}}( \pm 10)$ & $46.3^{\mathrm{d}}( \pm 2.4)$ \\
Cooked charqui meat & $0.093^{\mathrm{a}}( \pm 0.017)$ & $300^{\mathrm{a}}( \pm 13)$ & $31.7^{\mathrm{e}}( \pm 1.2)$ \\
Desalted charqui & - & $47^{\mathrm{c}}( \pm 2)$ & $58.9^{\mathrm{c}}( \pm 0.9)$ \\
Desalted cooked charqui & - & $86^{\mathrm{b}}( \pm 6)$ & $44.8^{\mathrm{d}}( \pm 0.6)$ \\
\hline
\end{tabular}

$\overline{a, b, c, d, e, ~ R o w ~ m e a n s ~ w i t h ~ c o m m o n ~ s u p e r s c r i p t s ~ d o ~ n o t ~ d i f f e r ~}(\mathrm{P}>0.05)$ 


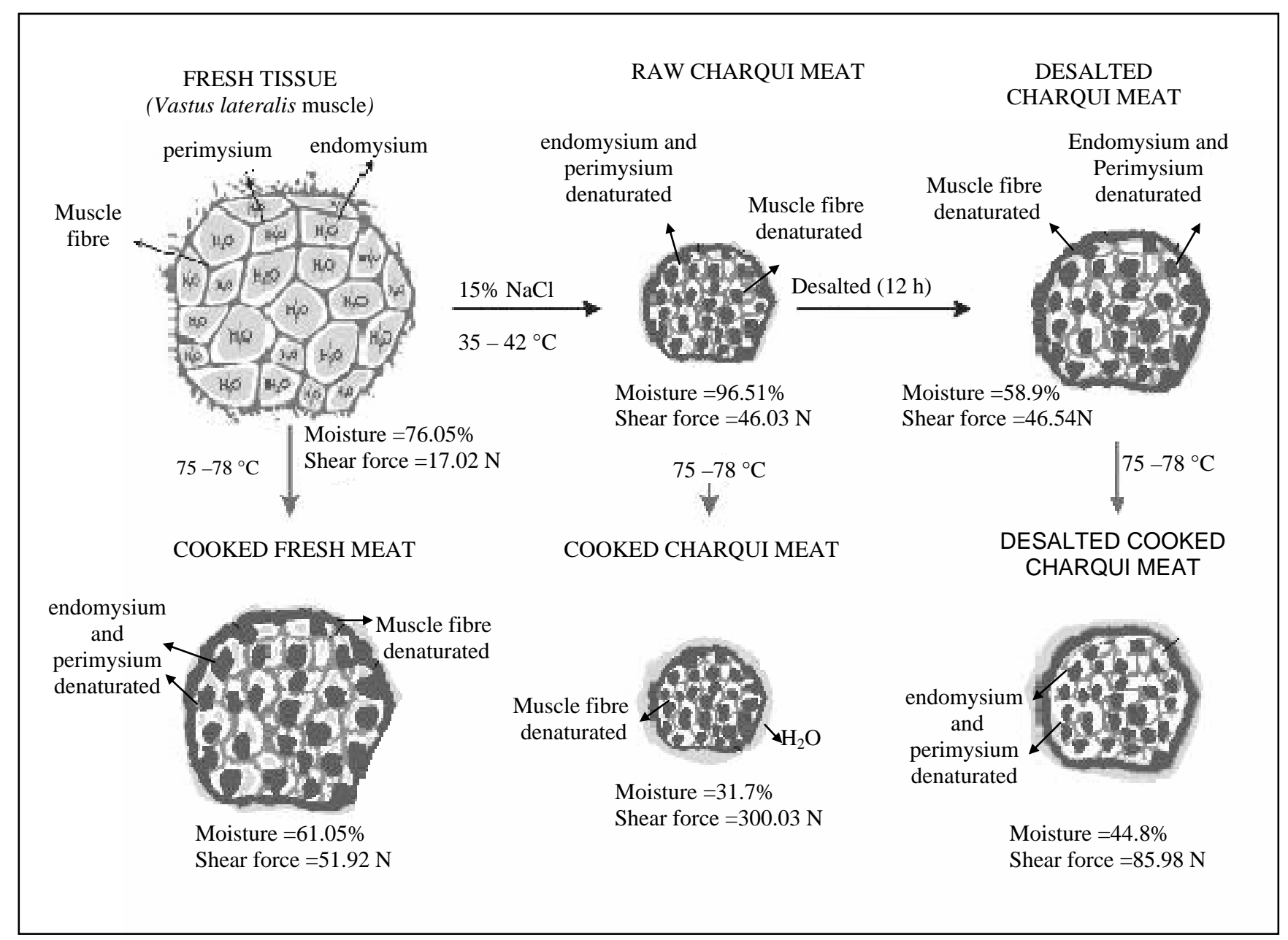

Figure 1 - Schematic representation of charqui meat structural changes throughout its processing from fresh tissue to desalted charqui meat and its respective heat treatment

The results of moisture evaluation in various charqui preparations are shown in Table 2. Cooked CHM had the lowest moisture value, followed sequentially by the uncooked, cooked fresh tissue and finally, by the fresh tissue samples. As pointed out in Avery et al. (1996), collagen denatures upon cooking and shrinks. Resistance from the denatured muscle proteins leads to a tension that squeezes the water out, making the meat tougher, particularly in mature animals. Since there is a need for desalting, followed by cooking procedures in order to make it palatable the desalted uncooked charqui samples had higher moisture content in relation to cooked CHM. By relating the moisture content with shear values, it could be observed that the higher the moisture content the more tender was the CHM. The desalted charqui in turn absorbed water (ca. 13\%, presumably as capillary water). In fact, it had the highest moisture content; concomitantly it was the most tender sample among the charqui samples analyzed. After cooking, there was a loss of ca. $14.6 \%$ of water compared to the uncooked desalted CHM sample. The high texture value generated during the muscle shrinkage throughout charqui processing was partially alleviated by the addition of water on desalting. The presence of capillary water would help to reduce the shear values for CHM. On the other hand, although there was approximately double the lipid fraction in charqui, this did not seem to influence the texture (Table 1). Furthermore, the relatively high density ratio of muscle protein to collagen (29:1; see Table 1), substantiated the assumption that collagen and its crosslinking were not the main factor influencing charqui meat tenderness. All these 
results indicated that moisture content the primary cause of CHM was texture. Fig. 1 summarizes all these processing events relating them to samples texture.

Equation (1) provided the best fit correlating the texture values (shear force) as functions of HP concentration and moisture contents:

$\ln (\mathrm{SF})=7.6495+0.0932 * \ln (\mathrm{HP})-0.0604 *\left(\mathrm{H}_{2} \mathrm{O}\right)$

$\mathrm{R}^{2}=0.94, \mathrm{p}<0.0001, \mathrm{n}=36$

where $\mathrm{SF}=$ shear force $(\mathrm{N})$

$\mathrm{HP}=$ hydroxylysylpyridinium concentration (mol $\mathrm{HP} / 100 \mathrm{~g}$ of sample)

$\mathrm{H}_{2} \mathrm{O}=$ moisture content $(\mathrm{g} / 100 \mathrm{~g}$ of sample)

$\mathrm{R}^{2}=$ coefficient of determination

$\mathrm{P}=$ level of significance of the adjusted function

$\mathrm{n}=$ number of samples

Equation (1) also revealed a good fit with the experimental data showing that the meat samples shear force increased exponentially with the loss of moisture, and conversely, increased linearly with HP concentration.

In conclusion, collagen and its heat stable mature collagen crosslink, hydroxylysylpyridinium, were not the primary cause for the texture in intermediate moisture meat products. The resulting texture was a result of a multitude of factors most probably involving myofibril proteins that promoted the dynamic biochemical events particularly associated with the water. The presence of this residual quantity of water influenced the ultimate texture of charqui meats.

\section{ACKNOWLEDGEMENTS}

We thank to FRIPAR for the meat samples and to Prof. A. J. Bailey (University of Bristol, UK) for a sample of an authentic hydroxylysylpyridinium (HP) standard. EYY and CERG were recipients of CAPES graduate student scholarship. MS is a CNPq Research Fellow.

\section{RESUMO}

Este trabalho avaliou a relação entre a composição química aproximada do charque (CHM) com a maciez durante todas as etapas de sua produção. CHM foi produzida do $\mathrm{m}$. Vastus lateralis bovino (patinho) de aproximadamente 4-5 anos de idade.
A força de cisalhamento do charque cru mostrou o valor aproximado de 3 vezes maior em dureza comparada à matéria prima enquanto que no caso do CHM cozido houve 6 vezes maior em aumento sob as mesmas condições.O índice de umidade diminui de 39 a $58 \%(\mathrm{p}<0,05)$ para CHM cru e cozido, respectivamente, em relação à matéria prima. O modelo matemático da influência destes componentes mostrou que a força de cisalhamento aumentou exponencialmente com a perda de umidade. A textura do charque é o resultado da associação de multifatores envolvendo proteínas miofibrilares que provocam eventos bioquímicos dinâmicos como a sua ligação com as moléculas da água. É a quantidade destas que determina a textura final do charque.

\section{REFERENCES}

AOAC, (1995), Official Methods of Analysis (16th ed.). Association of Official Analytical Chemists, Inc., Washington, DC, USA.

Avery, N.C.; Sims T.J.; Warkup, C. and Bailey, A.J., (1996), Collagen cross-linking in porcine $M$. longissimus lumborum: absence of a relationship with variation in texture at pork weight. Meat Sci. 42, 355369.

Bailey, A.J. and Shimokomaki, M., (1971), Age related changes in the reducible crosslinks of collagen. FEBS Letters 16, 86-88.

Biscontini, T.M.B.; Shimokomaki, M.; Oliveira, S.F. and Zorn, T.M.T., (1996), An ultrastructural observation on charquis, salted and intermediate moisture meat product. Meat Sci 43, 351-358.

Bosselmann, A.; Möller, C.; Steinhardt, H.; Kirchgessner, M. and Schwarz, F.J., (1995), Pyridinoline cross-links in bovine muscle collagen. $J$. Food Sci. 60, 953-958.

Bouton, P.E.; Harris, P.V. and Shorthose, W.R., (1971), Effect of ultimate $\mathrm{pH}$ upon the water-holding capacity and tenderness of mutton. J. Food Sci., 36, 435-439.

Brasil, (1962), Ministério da Agricultura. Departamento Nacional de Inspeção de Produtos de Origem Animal. Rio de Janeiro.

Chang, F.S.; Huang, T.C. and Pearson, A.M., (1996), Control of the dehydration process in production of intermediate moisture meat products: a review. $A d v$. Food Nutr. Res. 29, 71-161.

Coró, F.A.G.; Youssef, E.Y. and Shimokomaki, M., (2002), Age related changes in poultry breast meat collagen pyridinoline and texture. J. Food Biochemistry 26, 533-541. 
Eyre, D.R. and Oguchi, H., (1980), The hydroxypyridinium crosslinks of skeletal collagens. Their measurement, properties and proposed pathways of formation. Biochem. Biophys. Res. Commun. 92, 403-410.

Eyre, D.R.; Koob, T.J. and Van Ness, K.P. (1984), Quantitation of hydroxypyridinium crosslinks in collagen by high performance liquid chromatography. Anal. Biochem. 137, 380-388.

Eyre, D.R., (1987), Collagen cross-linking aminoacids. Meth. Enzymol. 144, 115-139.

Fujimoto, D., Akiba, K. and Nakamura, K., (1977), Isolation and characterization of a fluorescent material in bovine Achilles tendon collagen. Biochem. Biophys. Res. Commun. 76, 1124-1129.

Kolar, K. (1990), Colorimetric determination of hydroxyproline as measure of collagen content in meat and meat products: NMKL collaborative study. Journal of AOAC International Gaithersburg, 71, 5457

Leistner, L., (1987), Shelf stable product and intermediate moisture foods based on meat. In-Water Activity Theory and Application to Food. Marcel Dekker Inc., New York, pp 295-328.

Nakano, T.; Thompson, J.R. and Aherne, F.X., (1991), Concentration of the crosslink pyridinoline in porcine skeletal muscle epimysium. Can. J. Inst. Food Sci. Technol. 18, 100-102.

Pinto, M.F.; Franco, B.D.G.M. and Shimokomaki, M., (1998), Controle de Staphylococcus aureus em charques (jerked beef) por culturas iniciadoras. Ciênc. Tecnol. Alim. 18, 200-204.

Robins, S.P.; Shimokomaki, M. and Bailey, A..J., (1973), The Chemistry of the collagen cross-links. Age related changes in the reducible components of intact collagen fibres. Biochem. J. 131, 771-780.

Shimokomaki, M.; Elsden, D.F. and Bailey, A.J., (1972), Meat tenderness: age related changes in bovine intramuscular collagen. J. Food Sci. 37, 892896.
Shimokomaki, M.; Franco, B.D.G.M.; Biscontini, T.M.; Pinto, M.F.; Terra, N.N. and Zorn, T.M.T., (1998), Charqui meats are hurdle technology meat products. Food Rev. Int. 14, 339-349.

Shimokomaki, M.; Youssef, E.Y. and Terra, N.N., (2003), Curing. In: Encyclopaedia of Food Science and Nutrition (2nd ed.). Eds. Caballero, B.; Trugo, L.P. and Finglas, E., Academic Press, London, pp 1702-1708.

Skinner, S. J. M., (1982), Rapid method for purification of the elastin crosslinks, desmosine and isodesmosine. J. Chromatogr. 229, 200-204.

STATSOFT, 1995, Statistics for Windows, v. 5.0, Statsoft Inc., Tulsa.

Steinhardt, H., Bosselmann, A. and Möller, C., (1994), Determination of pyridinolines in bovine collagenous tissue. J. Agr. Food Chem. 42, 1943-1947.

Torres, E.A.F.S.; Shimokomaki, M.; Franco, B.D.G.M.; Landgraf, M.; Carvalho Jr, B.C. and Santos, J.C., (1994), Parameters determining the quality of charqui, an intermediate moisture meat product. Meat Sci. 38, 229-234.

Woessner, J.F., (1961), The determination of hydroxyproline in tissue and protein samples containing small proportions of this aminoacid. Arch. Biochem. Biophys. 93, 440-447.
Received: January 18, 2005; Revised: August 04, 2006; Accepted: March 14, 2007. 